\title{
Assessment of the ecotoxicity of bismuth at the phytotoxicity of soils
}

\author{
Lyudmila Sudina, ${ }^{*}$, Sergey Kolesnikov, Tatiana Minnikova, Tigran Ter-Misakyants ,Helena \\ Nevedomaya, and Kamil Kazeev \\ Southern Federal University, Stachki Ave., 194/1, Rostov-on-Don, 344090, Russian Federation
}

\begin{abstract}
The results of the study of the ecotoxicity of bismuth on ordinary chernozem, brown forest soils and sierosands along the length of radish roots are presented. Small doses of $1.5-3 \mathrm{mg} / \mathrm{kg}$ of bismuth stimulated the growth of radish roots on ordinary chernozem. The maximum toxicity of bismuth carbonate and nitrate at a dose of $300 \mathrm{mg} /$ $\mathrm{kg}$ was established on sierosands (reduction in the length of radish roots by $43 \%$ of the control). Bismuth carbonate $300 \mathrm{mg} / \mathrm{kg}$ showed the greatest toxicity when applied to ordinary chernozem and brown forest soil and reduced the length of radish roots by 31 and $44 \%$ of control, respectively. The series of toxicity ((on radish's root length) of chemical forms of bismuth for soils forms the following sequence: bismuth carbonate $(84) \geq$ bismuth nitrate $(86)>$ bismuth oxide (90). The toxic effect of bismuth depends on the form and concentration of bismuth in the soil,the particlesize composition, the reaction of the soil environment and the content of organic matter in the soil.
\end{abstract}

\section{Introduction}

Soil contamination with heavy metals, including bismuth, can have a negative impact on both the functions of soil ecosystems and the safety of agriculture [1,2]. Bismuth compounds are now increasingly use in various industries as an alternative to toxic lead [3]. Among heavy metals, bismuth is characterized by a low content in the earth's crust [4]. However, in modern technologies, bismuth is use on a par with nitrogen, carbon and chlorine [5]. The main sources of bismuth pollution of the environment, including soils, are ferrous and non-ferrous metallurgy, motor transport, coal-fired thermal power plants, and the mining industry [6-9]. This widespread use of bismuth increases its gross content in the soil. As a result, the concentration of bismuth in the soil can reach $930-1891 \mathrm{mg} / \mathrm{kg}$, exceeding the background content by 100-300 times [8,9]. Accumulating in the soil in high concentrations, like other heavy metals, bismuthinevitably enters the plants. Its maximum accumulation is characteristic of plant roots $[4,10]$. The study of the effects of various chemical forms of heavy metals on soils is of interest to assess their possible mobility, bioavailability and toxicity.

Soil phytotoxicity is the property of the soil to inhibit the growth and development of

*Correspondingauthor:malusik_07@inbox.ru 
higher plants. The need for a definition of this indicator occurs when the monitoring of chemical contamination of soils. One of the mechanisms of phytotoxicity of heavy metals is the formation of excess reactive oxygen species, which leads to oxidative stress in plant cells [11]. Another mechanism of phytotoxicity is the substitution of essential elements $(\mathrm{Cd}-\mathrm{Zn}, \mathrm{Se}-\mathrm{S})$ or the binding of heavy metals by enzymes, which leads to a violation of their function. In large quantities, essential chemical elements are toxic to plants and disrupt the functions of enzymes. As a result, plants synthesize more toxic thiol compounds [12]. Bismuth is not an essential element. However, it was previously established that bismuth can affect the transport of iron in plant cells [10]. Since the effects of bismuth on plants and soils are currently poorly understood, this determined the relevance of this study.

The aim of the study is to assess the ecotoxicity of bismuth by the phytotoxicity of soils.

\section{Material and Methods}

\subsection{Soil samples}

Soils of the South of Russia, significantly differing in properties determining the sustainabilityto heavy metal pollution, were used as objects of study: ordinary chernozem (Botanical Garden of SFU, the Rostov-on-Don city, 47 $14^{\prime} 17.54 \mathrm{~N}, 39^{\circ} 38^{\prime} 33.22 \mathrm{E}$ ), sierosands (the Rostov Region, the Ust'-Donetsk Region, $47^{\circ} 46.015^{\prime} \mathrm{N} 40^{\circ} 51.700^{\prime} \mathrm{E}$ ), and brown forest acidic soil (the Republic of Adygea, the Maykopsky district, Nikel settlement, $44^{\circ} 10.649^{\prime} \mathrm{N}, 40^{\circ} 9.469^{\prime} \mathrm{E}$ ). These different types of soils are chosen for the study, because they are often used for agricultural crops on South of Russia. Ordinary chernozem according to IUSS Working Group WRB [13] as Haplic Chernozems(Loamic) is characterized by a heavy loam the particle-size composition, an average organic matter content $-3.7 \%$ and a reaction of soil $\mathrm{pH}=7.8$ (slightly alkaline). Sierosands or Haplic Arenosols (Eutric) are characterized by light particle-size composition; low organic matter content- $2.3 \%$ and reaction of soilpH, 6.8 (neutral). Brown forest soils or Haplic Cambisols (Eutric) are characterized by heavy loam the particle-size compositionloworganic matter content $-1.8 \%$; and reaction of soil $\mathrm{pH}=5.8$ (acid).

\subsection{Experimental details}

Soil samples were taken from the upper soil layer $(0-10 \mathrm{~cm})$ because heavy metals are retained in it [4]. The soil samples differed in the types of land: arable land (ordinary chernozem), grass-grass steppe (sierosands) and beech-hornbeam forest (brown forest soil). The background content of bismuth in the objects of the study is $0.27,0.28$ and $0.14 \mathrm{mg} / \mathrm{kg}$, respectively, in ordinary chernozem, brown forest soil and sierosands. The bismuth content was determined by inductively coupled plasma mass spectrometry (ICP-MS) at the AllRussian Geological Research Institute named after A. P. Karpinsky (St. Petersburg).

The analysis of the literature data did not reveal the forms in which bismuth compounds enter the soil. Probably, it can be oxides, as well as soluble and insoluble salts. These forms of compounds are typical for most heavy metals that pollute the soil [4].The study evaluated the phytotoxic properties of soils, since they are the first to react to chemical contamination. The phytotoxic properties of the soils were evaluated after 10 days of contamination. A longer incubation period increases the differences in the state of the soil incubated in the laboratory from its state in natural conditions. The simulation of the experiment on soil contamination was carried outin triplicateunder laboratory conditions using the methods generally accepted in soil biology and ecology [14]. 
Bismuth (III) compounds were studied, since the trivalent state of bismuth is the most stable in nature [15]. According to authors [6-11], it was found that contaminated soils can contain bismuth in concentrations ranging from $1.5 \mathrm{mg} / \mathrm{kg}$ till $436 \mathrm{mg} / \mathrm{kg}$ and more then. The soils were polluted with bismuth oxide $\mathrm{Bi}_{2} \mathrm{O}_{3}$, bismuth carbonate $(\mathrm{BiO})_{2} \mathrm{CO}_{3}$, and bismuth nitrate $\mathrm{Bi}\left(\mathrm{NO}_{3}\right)_{3}$ in different concentrations $-1.5,3,15,30,150$ and $300 \mathrm{mg} / \mathrm{kg}$. Taking into account the solubility of the compounds, the application of bismuth oxide, carbonate, and nitrate to the soil differed. Bismuth nitrate was dissolved in water and introduced into the soil at the first watering. Bismuth oxide and carbonate were ground with a small amount of dry soil. Then the soil was thoroughly mixed with the rest of the soil of the incubation vessel, after which watering was carried out. The soil $(0.5 \mathrm{~kg})$ was incubated at optimal humidity ( $60 \%$ of the field moisture capacity) and a temperature of $20-22^{\circ} \mathrm{C}$ in triplicated.

Sustainability in the right sense was evaluated by the length of the radish roots in relation to different doses of bismuth. According to [16], roots are more sensitive to heavy metal contamination by plant organs than shoots. Based on this, the phytotoxicity of soils was calculated by changing the length of the roots of radish (Raphanussativus L.). The change in the length of radish roots in the studied soils was expressed as a percentage relative to the control. The selected seeds were placed evenly in 5 rows of 5 seeds in Petri dishes with soil. Each variant of each soil type and form of chemical compound was studied in triplicate with subsequent statistical processing $(n=225: 3$ vegetative vessels in 3 biologicalreplicatesin Petri dishes $\times 25$ radish seeds). The control was non-polluted soil with bismuth, selected from the studied areas.

\subsection{Statistical analyses}

To check the reliability of the results, an analysis of variance was carried out followed by the determination of the least significant difference (LSD). Variation statistics (mean values, dispersion) was determined, reliability of different samples was established by using dispersion analysis (Student- $t$ ) and the correlation analysis (Pearson correlation coefficient) was conducted.

\section{Results and Discussion}

\subsection{Changes the radish's root length of chernozem ordinary upon contamination with bismuth}

With the introduction of small doses of all chemical forms of bismuth (1.5 and $3 \mathrm{mg} / \mathrm{kg})$ in ordinary chernozem, statistically unreliable stimulation of the radish root system was recorded (Fig.1). The stimulating effect of bismuth nanoparticles at a dose of 2.8 and 5.6 $\mathrm{mg} / \mathrm{kg}$ on seed germination of spring wheat by 10 and $30 \%$ was previously established [17]. In the course of the experiment, the length of radish roots decreased in inverse proportion to the applied doses of all chemical compounds of bismuth to the soil by 15 $31 \%$ of control. With the introduction of bismuth oxide in doses of 150 and $300 \mathrm{mg} / \mathrm{kg}$, the root length indices decreased by 15 and $22 \%$ of control. The introduction of bismuth carbonate in doses of $30-300 \mathrm{mg} / \mathrm{kg}$ inhibited the radish root system by $18-31 \%$ of control. Bismuth nitrate, when applied at $30-300 \mathrm{mg} / \mathrm{kg}$, showed a toxic effect and reduced the length of radish roots by $16-23 \%$ of control.

T. Nagata (2015) obtained similar results when studying the effect of bismuth nitrate on Arabidopsis thaliana. Small doses of bismuth 0.1 and $1 \mu \mathrm{M}$ did not affect the growth of the plant root system and even stimulated root growth by $10-20 \%$ [10]. With an increase in the 
concentration of bismuth to $2 \mu \mathrm{M}$, the length of Arabidopsis thaliana roots decreased by $50 \%$ from the control values. Bismuth nitrate at concentrations of 2 and $3 \mu \mathrm{M}$ inhibited plant root growth and increased lateral root growth. The highest bismuth concentration of $6 \mu \mathrm{M}$ significantly reduced the root growth of Arabidopsis thaliana.

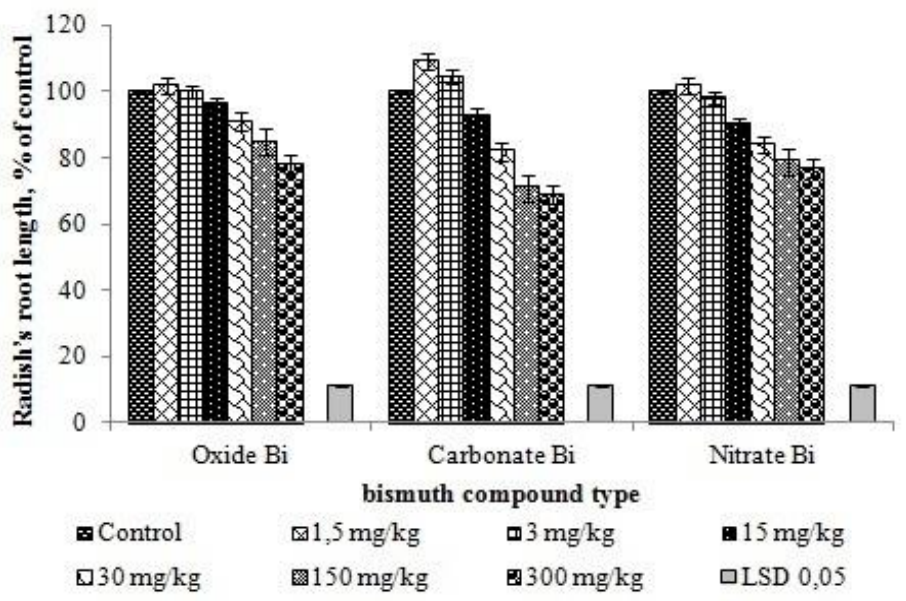

Fig.1. Effects on bismuth in contaminated chernozem ordinary on radish's root length, \% of control

\subsection{Changes the radish's root length of brown forest soil upon contamination with bismuth}

When low concentrations of 1.5 and $3 \mathrm{mg} / \mathrm{kg}$ of nitrate and bismuth oxide were introduced into brown forest soil, no statistically significant differences from the control were observed (Fig. 2). A statistically significant decrease in the length of radish roots was recorded when $15 \mathrm{mg} / \mathrm{kg}$ of oxide, carbonate and bismuth nitrate by 13,14 and $15 \%$ of control, respectively. When a dose of $30 \mathrm{mg} / \mathrm{kg}$ of bismuth oxide, carbonate, and nitrate were introduced into brown forest soil, the root length decreased by 15, 29, and $18 \%$ of control. Concentrations of bismuth oxide 150 and $300 \mathrm{mg} / \mathrm{kg}$ and bismuth nitrate at a dose of 150 $\mathrm{mg} / \mathrm{kg}$ equally inhibited the length of plant roots by $26 \%$ of control. The introduction of a dose of $30-300 \mathrm{mg} / \mathrm{kg}$ of bismuth carbonate and nitrate reduced the growth of the radish root system by $18-42 \%$ of control. 


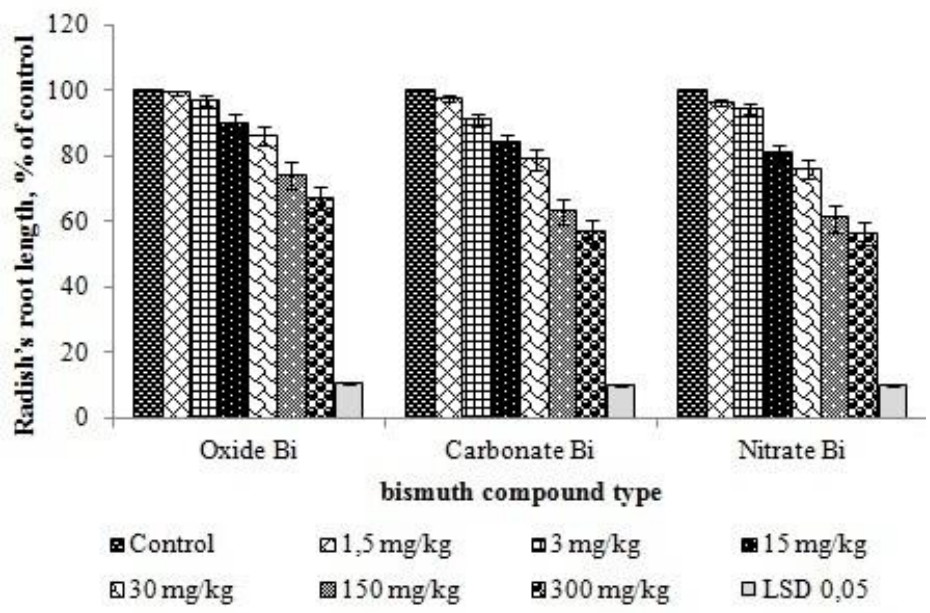

Fig. 2. Effects on bismuth in contaminated brown forest soil on radish's root length, \% of control

\subsection{Changes the radish's root length of sierosands upon contamination with bismuth}

When sierosands were contaminated with low doses of bismuth $(1.5$ and $3 \mathrm{mg} / \mathrm{kg})$ of all chemical forms, as well as when applied to brown forest soil, no statistically significant differences in the length of radish roots from the control values were found (Fig. 3).

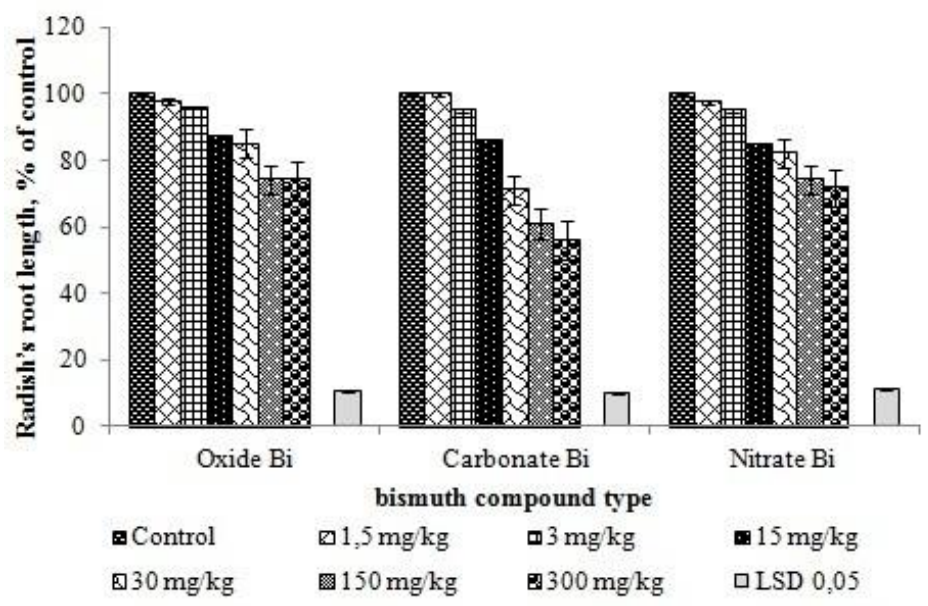

Fig. 3. Effects on bismuth in contaminated sierosands on radish's root length, $\%$ of control

A statistically significant decrease in the length of radish roots was recorded at a concentration of bismuth carbonate and nitrate of $15 \mathrm{mg} / \mathrm{kg}$ by 16 and $19 \%$, respectively, of control. A statistically significant inhibition of radish roots was established when $30 \mathrm{mg} / \mathrm{kg}$ of bismuth oxide and nitrate was added to $14 \%$ of control. Bismuth oxide at doses of 150 and $300 \mathrm{mg} / \mathrm{kg}$ inhibited the radish root system by $26-33 \%$ of control. The addition of 150 $\mathrm{mg} / \mathrm{kg}$ of bismuth nitrate reduced the root length by $39 \%$ of control. In this case, when 
added to sierosands, bismuth nitrate showed slightly greater toxicity than the same doses of bismuth oxide and carbonate. Bismuth carbonate and nitrate, when added to sierosands 300 $\mathrm{mg} / \mathrm{kg}$, equally inhibited the radish root system by $43 \%$. With an increase in the concentration of bismuth nitrate to 4 and $5 \mu \mathrm{M}$ in Arabidopsis thaliana, the absence of the formation of normal tissues of the root system was observed [12].

\subsection{Comparative assessment of the toxicity of bismuth compounds by the length of radish roots grown on different soils}

An assessment was made of the ecotoxicity of bismuth compounds and the fsustainabilityof soils to contamination with bismuth along the length of the radish roots. Based on the chemical form of the pollutant, the averaged range of toxicity of bismuth for soils along the length of the radish roots is:

bismuth carbonate (84) $\geq$ bismuth nitrate (86) $>$ bismuth oxide (90).

The biological effect of the effect of bismuth on plants depends not only on the dose, but also on the form of being in soils [9]. Bismuth oxide, as a less soluble substance in the soil, had a less toxic effect. Previously, the highest toxicity of nitrate ions was established when studying the biological properties of soils in Southern Russia [18]. In the present study, bismuth carbonate is the most toxic substance. This fact requires further deeper study.

Similar results in assessing the phytotoxicity of silver were obtained by N.I. Tsepina et al. (2020). The authors observed a decrease in the length of the roots of radish grown on ordinary chernozem, sierosands and brown forest soil by 17,24 , and $29 \%$ of control, respectively, when the maximum dose of silver was applied to $100 \mathrm{mg} / \mathrm{kg}$ [19].

With an increase in soil $\mathrm{pH}$, bound fractions of heavy metals increase due to the formation of a large number of $\mathrm{pH}$-dependent cation-exchange sites on the soil surface and an increase in the stability constants of metal complexes with fulvic acids and humic acids [20]. A. KabataPendiasand X. Pendias(2010) established the formation of stable carbonates by bismuth in neutral soil [4]. Bismuth carbonates are not stable in acidic soils, compared to neutral and alkaline soils [21]. Carboxyl groups play a major role in the solubility of $\mathrm{Bi}$ in acidic and neutral media, while phenolic-OH, amino groups, and thiol groups (-SH) play an important role in neutral and alkaline media [22].The presence of a large amount of easily decomposed organic matter in the upper layers in the acidic brown forest soil contributes to the formation of a large number of soluble complexes of bismuth with organic matter [23]. Soil acidification increases the mobility and availability of many elements, including bismuth [24]. Thus, bismuth in ordinary chernozem exhibits the lowest ecotoxicity (on radish's root length) in comparison with other types of soils.

\section{Conclusion}

As a result of a study of the ecotoxicity of bismuth for phytotoxicity of different types of soils, a decrease in the length of radish roots was established. Low concentrations of 1.5-3 $\mathrm{mg} / \mathrm{kg}$ of all chemical forms of bismuth had a stimulating effect on the length of the roots of radish on ordinary chernozem. The highest toxicity of bismuth carbonate and nitrate at a concentration of $300 \mathrm{mg} / \mathrm{kg}$ was found on sierosands (reduction in the length of radish roots by $43 \%$ from control). On ordinary chernozem and brown forest soil, the highest toxicity was foundwith the introduction of $300 \mathrm{mg} / \mathrm{kg}$ of bismuth carbonate -31 and $44 \%$ of control, respectively. The series of toxicity of chemical forms of bismuth for soils (on radish's root length) forms the following sequence: bismuth carbonate $(84) \geq$ bismuth nitrate (86)> bismuth oxide (90). The toxic effect of bismuth depends on the form and 
concentration of the element in the soil, the particle-size composition, the reaction of the soil environment and the content of organic matter in the soil. The greatest rsustainability to bismuth contamination of radishes grown on ordinary chernozem is due tothe particle-size compositionof the soil, the high content of organic matter (3.7\%) and the slightly alkaline reaction of the soil $(\mathrm{pH}=7.8)$. Bismuth is mobile in brown forest soil with an acidic reaction of the soil environment $(\mathrm{pH}=5.8)$, and has a toxic effect on the root system of radish. The low toxicity of bismuth (on radish's root length) in the sierosands was established. The light particle-size composition of sierosands does not provide sufficient absorption capacity to fix bismuth in the soil, which requires further research.

Authors would also like to express acknowledgements to the criticism and constructive comments of the anonymous referees.

The study was carried out with the support of the Ministry of Science and Higher Education of the Russian Federation within the framework of a state assignment (Southern Federal University, project No. 0852-2020-0029) and state support of the leading scientific schools of the Russian Federation (grant of the President of the Russian Federation SSc-2511.2020.11).

\section{References}

1. B.J. AllowayHeavy Metals in Soils: Trace Metals and Metalloids in Soils and theirBioavailability(New York, Springer, 2010)

2. I. Zamulina, M. Burachevskaya, S. Mandzhieva, T. Bauer, A.Barakhov, M. Mazarji., E3S Web of Conferences 169, 01025 (2020)

3. Directive on the restriction of the use of certain hazardous substances in electrical and electronic equipment. J. ref. Eurlex.Eur.EU L., 37, 19-23 (2003)

4. A. Kabata-Pendias and X. Pendias, Trace Elements in Soils and Plants (BocaRaton, FL. CrcPress, 2010)

5. N. Kasimov and D. Vlasov, Vestnik Moskovskogo universiteta. Seriya 5, Geografiya, 5, 15-22 (2012)

6. F. Cabrera,L. Clemente, E. D1' az Barrientos,Sci. Total. Environ. 242, 117-129 (1999)

7. M.C. Jung, I. Thronton, H.-T. Chon, Sci. Total Environ., 3, 81-89 (2002)

8. C.C. Elekes and G. Busuioc, Lat. Trends Engineer. Edu., 1, 36-39 (2010)

9. G. Yurgenson and D. Gorban, Internat. J. AppliedFundament. Res., 7, 111-116 (2017)

10. T.Nagata,J. Plant Biol., 58, 311-317 (2015)

11. P. Babula, V. Adam, R. Opatrilova, J. Zehnalek, L. Havel, R. Kizek, Environ. Chem. Lett., 6, 189-213 (2008)

12. J. Petrlova, R. Mikelova, K. Stejskal, A. Kleckerova, O. Zitka, J. Petrek, L. Havel, J. Zehnalek, V. Adam, L. Trnkova, R. Kizek, J. Sep. Sci., 29,1166-1173 (2006)

13. IUSS Working Group WRB (Rome, FAO. 2014, Update 2015).

14. K.S. Kazeev, S.I. Kolesnikov, Y.V. Akimenko, E.V. DadenkoMethods of biodiagnostics of terrestrialecosystems (SfeduPublishing house, Rostov-on-Don, 356, 2016)

15. A.V. Egorysheva, O.G. Ellert, Y.V. Zubavichus, O.M. Gajtko, N.N. Efimov, R.D. Svetogorov, V.Y. Murzin, J. Solid State Chem., 225, 97-104 (2015)

16. R.M. Daoud, S.I. Kolesnikov, A.A. Kuzina, K.Sh. Kazeev, Yu.V. Akimenko, Izvestiya vuzov. Severo-Kavkazskii region. Natural science, 2, 90-96 (2019)

17. V.Skrybin, Theses 13-th All Russian science conference. 06-10 June 2016 (Anapa KF FGBNU «VNIIZ», 613-618, 2016) 
18. S.I. Kolesnikov, N.I. Tsepina, L.V. Sudina, T.V. Minnikova, K.Sh. Kazeev, Yu.V. Akimenko, Appl. Environ. Soil Sci., 2020, 1207210 (2020)

19. N.I. Tsepina, T.V. Minnikova, S.I. Kolesnikov, K.Sh. Kazeev, Bull. High. Educat. inst. NorthCaucasusregion. Natural science, 3, 107-112 (2020)

20. H. Hou, T. Takamatsu, M. K. Koshikawa, M. Hosomi, J. SoilSci., 57, 214-227 (2006)

21. T. Takamatsu, T. Murata, M.K. Koshikawa, M. Watanabe, Arch. Environ. Contam. Toxicol.,59, 91-99 (2010)

22. T. Murata, J. Environ. Sci. Health A. Tox. Hazard Subst. Environ. Eng., 45(6), 746-53 (2010)

23. T. Murata, J. Environ. Sci. Health A. Tox. Hazard Subst. Environ. Eng., 41(2), 161-72 (2006)

24. S.A. Watmough, Water, Air and SoilPollut.,136, 165-187 (2002) 